\title{
AIMP2 Gene
}

National Cancer Institute

\section{Source}

National Cancer Institute. AIMP2 Gene. NCI Thesaurus. Code C97241.

This gene plays a role in the regulation of both ubiquitination and translation. 